\title{
Mate extract on lipid and color changes of dourado fillets during frozen storage
}

\author{
Extrato de mate sobre alterações lipídicas e de cor de filés de dourado durante o \\ armazenamento congelado
}

\author{
Ana Paula de Lima Veeck ${ }^{\mathrm{III}}$ Aline Augusti Boligon ${ }^{\mathrm{III}}$ Margareth Linde Athayde ${ }^{\mathrm{III}}$ \\ Tatiana Emanuelli ${ }^{I^{*}}$
}

\section{ABSTRACT}

This study aimed to evaluate whether mate (Ilex paraguariensis A. St. Hil) extract would change lipid and color stability of dourado (Salminus brasiliensis) fillets during frozen storage. Fish fillets were dipped (1 min) in distilled water (control) or in aqueous extract of mate $\left(0.1 \mathrm{~g} \mathrm{~mL}^{-1}, w / \mathrm{v}\right)$ and were stored at $-7^{\circ} \mathrm{C}$ for up to 12 months. Conjugated dienes $(C D)$ increased in control fillets after 6 months of storage and then decreased, whereas thiobarbituric acid reactive substances (TBARS) value increased along the whole experimental period. Mate treatment reduced CD and TBARS values of fillets. Dourado fillets tended to yellow along the whole experimental period (average $H^{*}=72.55$ ) Although the mate treatment had increased the yellowness of fillets at the start of storage, this treatment reduced the increase in luminosity $\left(L^{*}\right)$ and in yellowness $\left(H^{*}\right)$ triggered by frozen storage. Results indicate that mate extract inhibits lipid oxidation and some color changes caused by the frozen storage of fish fillets.

Key words: conjugated dienes, $T B A R S, D P P H$, Ilex paraguariensis A. St. Hil, Salminus brasiliensis.

\section{RESUMO}

Foi avaliado o efeito do extrato de mate (Ilex paraguariensis A. St. Hil) sobre as alterações lipídicas e de cor de filés de dourado (Salminus brasiliensis) durante o armazenamento congelado. Os filés foram mergulhados (1 min) em água destilada (controle) ou em extrato aquoso de mate $\left(0,1 \mathrm{~g} \mathrm{~mL} L^{-1}, \mathrm{p} / \mathrm{v}\right) \mathrm{e}$ armazenados a $-7^{\circ} \mathrm{C}$ por 12 meses. Os dienos conjugados (DC) aumentaram nos filés controle após 6 meses de armazenamento e então diminuíram, enquanto os valores de substâncias reativas ao ácido tiobarbitúrico (TBARS) aumentaram ao longo de todo período experimental. O extrato de mate reduziu os valores de DC e TBARS dos filés. Os filés de dourado tenderam ao amarelo ao longo de todo o período experimental (média do $H^{*}=72.55$ ).
Ainda que o tratamento com mate tenha aumentado a intensidade de amarelo dos filés no início da armazenagem, esse tratamento reduziu o aumento da luminosidade $\left(L^{*}\right)$ e da intensidade de amarelo $\left(H^{*}\right)$, promovidos pelo armazenamento congelado. Os resultados indicam que o extrato de mate inibe a oxidação lipídica e algumas alterações de cor decorrentes do congelamento de filés de pescado.

Palavras-chave: dienos conjugados, TBARS, DPPH, Ilex paraguariensis A. St. Hil, Salminus brasiliensis.

\section{INTRODUCTION}

Dourado (Salminus brasiliensis) is a freshwater fish found in the Prata basin, central, and southern Brazil (KOCH et al., 2000). It is a large carnivorous species that has aquaculture potential to be used as food, sport, and ornamental fish (KOCH et al., 2000). Although dourado is much appreciated by the excellent quality of its flesh, studies concerning the processing and stability of its flesh are lacking.

Fish fillets are quite susceptible to oxidative reactions during frozen storage because they have high content of polyunsaturated fatty acids (HOSSEINI et al., 2010). This undesirable reaction results in unpleasant flavors and odors, and color change (VERMA et al., 1995). Some methods may be used to prevent or delay lipid oxidation during frozen storage such as the use of antioxidant substances. The interest for finding naturally occurring antioxidants

Instituto Federal de Santa Catarina (IFSC), Lages, SC, Brasil.

IINúcleo Integrado de Desenvolvimento em Análises Laboratoriais (NIDAL), Departamento de Tecnologia e Ciência dos Alimentos, Centro de Ciências Rurais (CCR), Universidade Federal de Santa Maria (UFSM), Camobi, 97105-900 Santa Maria, RS, Brasil. E-mail: tatiemanuelli@gmail.com.*Autor para correspondência.

IIIDepartamento de Farmácia Industrial, UFSM, Santa Maria, RS, Brasil 
for use in food products has grown, because many synthetic antioxidants were shown to be toxic or mutagenic (ANESINI et al., 2006). Some natural compounds such as anthocyanidins/anthocyanins, flavonoids, and phenolic acids have antioxidant activities similar to that of synthetic antioxidants (FUKUMOZO \& MAZZA, 2000; KRISHNAIAH et al., 2011).

Ilex paraguariensis Saint Hilaire (Aquafoliaceae) is popularly known as mate, ervamate, or yerba-mate (STREIT et al., 2007). It is widely consumed as a tea-like beverage in Argentina, Brazil, Paraguay, and Uruguay, but it is gaining rapid penetration into the USA and the European countries because of its alleged therapeutic capacity (VALERGA et al., 2012). It contains various caffeoylderivatives and other polyphenols that are responsible for its antioxidant properties (ANESINI et al., 2006; VALERGA et al., 2012; ANESINI et al., 2012). The antioxidant activity of $\boldsymbol{I}$. paraguariensis has been evaluated in biological systems both in vivo and in vitro (GUGLIUCCI, 1996; SCHINELLA et al., 2000; FILIP et al., 2000). However, few studies evaluated its antioxidant activity in food systems (CAMPOS et al., 2007; RACANICCI et al., 2008), but none in fish. Considering the potential antioxidant activity of mate extracts and the susceptibility of frozen fish to oxidative deterioration, the present study aimed to evaluate the effect of mate extract on lipid and color changes of dourado fillets during frozen storage.

\section{MATERIAL AND METHODS}

Commercial mate samples (dried and minced leaves and twigs of I. paraguariensis) were obtained from local market. Samples were weighed and mixed with distilled water $\left(0.1 \mathrm{~g} \mathrm{~mL}^{-1}, \mathrm{w} / \mathrm{v}\right)$ at room temperature and then filtered to yield the aqueous crude extract.

Samples of fresh eviscerated dourado (S. brasiliensis) were purchased from a local fish farm (Santa Maria, Brazil) and immediately transported to the laboratory in ice-containing boxes. Fish were washed with tap water several times to remove adhering blood and slime and were filleted using common household practices. The fillets (approximately 30g each) were dipped during $1 \mathrm{~min}$ in distilled water (control) or in the aqueous mate extract $\left(0.1 \mathrm{~g} \mathrm{~mL}^{-1}\right)$. Some fish samples were separated and immediately used to determine the instrumental color, fat content, and lipid oxidation. Another set of samples were stored in polystyrene trays covered with low density polyethylene film at $-7 \pm 1^{\circ} \mathrm{C}$ and were analyzed after 3, 6, and 12 months. This storage temperature was based on unpublished data from our laboratory showing that the lipid oxidation of fish products is accelerated at higher frozen temperatures $\left(-7^{\circ} \mathrm{C}\right)$ when compared to the storage at $-18^{\circ} \mathrm{C}$, but the type of changes observed at both temperatures are similar. A similar behavior was also observed for lipid oxidation of chicken meat stored at different frozen temperatures $\left(-7,-12\right.$, and $-18^{\circ} \mathrm{C}$ ) (SOYER et al., 2010). A total of 12 fish were used for each one of the two treatments in order to obtain three independent samples at each evaluation time.

The quantification of phenolic and flavonoid compounds of mate extract was obtained by HPLC-DAD using a Shimadzu Prominence system, equipped with Prominence Auto Sampler (SIL-20A), LC-20AT reciprocating pumps connected to the degasser DGU 20A5 with integrator CBM 20A, diode array detector SPD-M20A, and Software LC solution 1.22 SP1. Reverse phase chromatographic analyses were carried out under gradient conditions using $\mathrm{C}_{18}$ column $(4.6 \mathrm{~mm} \times 250 \mathrm{~mm})$ packed with $5 \mu \mathrm{m}$ diameter particles; the mobile phase was water containing 2\% acetic acid (A) and methanol (B), and the composition gradient was: $5 \%(\mathrm{~B})$ for $2 \mathrm{~min}$; 25\% (B) until 10min; 40, 50, 60, 70, and 80\% (B) every $10 \mathrm{~min}$. All the samples and mobile phase were filtered through $0.45 \mu \mathrm{m}$ membrane filter (Millipore) and then degassed by ultrasonic bath prior to use. Stock solutions of standard references were prepared in the HPLC mobile phase at a concentration range of $0.031-0.250 \mathrm{mg} \mathrm{mL}^{-1}$ for quercetin, rutin, and kaempferol, and $0.006-0.250 \mathrm{mg} \mathrm{mL}^{-1}$ for caffeic acid and theobromine. Quantification was carried out by integration of the peaks using the external standard method, at $270 \mathrm{~nm}$ for theobromine, $325 \mathrm{~nm}$ for caffeic acid, and $365 \mathrm{~nm}$ for quercetin, rutin, and kaempferol. The flow rate was $0.8 \mathrm{~mL} \mathrm{~min}^{-1}$ and the injection volume was $40 \mu \mathrm{L}$. The chromatography peaks were confirmed by comparing their retention time and diode-array-UV spectra with those of the reference standards. All chromatography operations were carried out at room temperature and in triplicate.

The antioxidant activity of mate extract was evaluated as the 1,1-diphenyl-2-picrylhydrazyl (DPPH) radical scavenging capacity (BRANDWILLIAMS et al., 1995). DPPH solution $(0.24 \mathrm{mg}$ $\left.\mathrm{mL}^{-1}\right)$ was previously diluted until $1.10 \pm 0.02$ absorbance at $517 \mathrm{~nm}$ was obtained. Then, the diluted sample extract $(1: 250, \mathrm{v} / \mathrm{v})$ was mixed with the diluted methanolic DPPH solution. The radical scavenging power of the extract was determined by measuring 
the decrease of DPPH absorbance at $517 \mathrm{~nm}$ after 24 hours in the dark against a blank. Trolox was used as standard for the calibration curve and results were expressed as $\mu \mathrm{g}$ trolox equivalents $\mathrm{mL}^{-1}$ extract.

For determination of thiobarbituric acid reactive substances (TBARS), samples (1g) of fillets were homogenized with $5 \mathrm{~mL}$ of an aqueous $\mathrm{KCl}$ solution

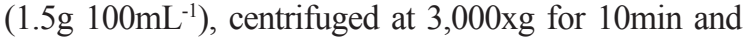
the supernatant was used as described by BUEGE \& AUST (1978). Fat was extracted and quantified according to BLIGH \& DYER (1959). Conjugated dienes (CD) values were determined in the fat using cyclohexane as solvent and recording the optical density (1cm light path) at $233 \mathrm{~nm}$ against a cyclohexane blank (RECKNAGEL \& GLENDE, 1984).

Sample color was assessed using a CR-300 Chromameter (Minolta, Osaka, Japan) according to the Intl. Commission on Illumination (CIE $1976 \mathrm{~L}^{*} \mathrm{a}^{*} \mathrm{~b}^{*}$ ), using a standard illumination D65, with $2^{\circ}$ supplementary standard observer and a standard calibration plate (number 15233011). Three measurements were recorded at each fillet, with the illumination system rotated $90^{\circ}$ between each measurement. The $\mathrm{L}^{*}$ indicates lightness and $a^{*}$ and $\mathrm{b}^{*}$ are the chromaticity coordinates, where $+\mathrm{a}^{*}$ is the red direction, $-\mathrm{a}^{*}$ is the green direction, $+\mathrm{b}^{*}$ is the yellow direction, $-b^{*}$ is the blue direction. The chroma $\left(\mathrm{C}^{*}\right)$ and hue $\left(\mathrm{H}^{*}\right)$ values were calculated from the $\mathrm{a}^{*}$ and $b^{*}$ values. The chroma is an expression of the saturation or intensity and clarity of the color. It is expressed by the equation; $\mathrm{C}^{*}=\left(\mathrm{a}^{* 2}+\mathrm{b}^{* 2}\right)^{1 / 2}$ (HUNT, 1977) and it is 0 at the center and increases according to the distance from the center. Hue is the observable color and is calculated by equation, $\mathrm{H}^{*}=\tan ^{-1}\left(\mathrm{~b}^{*} / \mathrm{a}^{*}\right)$ (HUNT, 1977). The angle $\mathrm{H}^{*}$ is defined as starting at the $+\mathrm{a}^{*}$ axis and is expressed in degrees; $0^{\circ}$ would be $+\mathrm{a}^{*}$ (red), $90^{\circ}$ would be $+\mathrm{b}^{*}$ (yellow), $180^{\circ}$ would be $-a^{*}$ (green), and $270^{\circ}$ would be $-b^{*}$ (blue).

The results were submitted to two-way factorial analysis of variance (ANOVA) (2 treatments $\mathrm{x} 4$ storage times or 2 treatments $\mathrm{x} 3$ storage times) and the differences among the treatments post hoc evaluated using Tukey's test. Differences were considered to be significant when $\mathrm{P}<0.05$.

\section{RESULTS AND DISCUSSION}

Since crude plant extracts usually contain a range of chemically diverse constituents at varying concentrations, it is important to use chromatographic methods to analyze these inherently complex mixtures. The HPLC profile of mate extracts revealed that rutin $\left(16.6 \pm 0.3 \mathrm{mg} \mathrm{g}^{-1}\right)$ and caffeic acid $\left(10.8 \pm 0.0 \mathrm{mg} \mathrm{g}^{-1}\right)$ were found at the highest concentration, followed by kaempferol $\left(6.7 \pm 0.3 \mathrm{mg} \mathrm{g}^{-1}\right)$, theobromine $(4.7 \pm 0.2 \mathrm{mg}$ $\left.\mathrm{g}^{-1}\right)$, and quercetin $\left(2.5 \pm 0.1 \mathrm{mg} \mathrm{g}^{-1}\right)$. Other nonidentified minor compounds were also found.

The DPPH radical scavenging capacity of the mate extract amounted to $25.8 \mathrm{mg}$ trolox equivalents $\mathrm{mL}^{-1}$ extract. This antioxidant capacity represents the amount of antioxidant extracted from $0.1 \mathrm{~g}$ mate, because the extract was obtained as $0.1 \mathrm{~g}$ mate for each $1 \mathrm{~mL}$ of water. Numerous active phytochemicals have been identified in $\boldsymbol{I}$. paraguariensis, as caffeoyl derivatives, mainly 3,5-dicaffeoylquinic, 4,5-dicaffeoylquinic, 3,4-dicaffeoylquinic, and chlorogenic acid, caffeic acid, and flavonoids (FILIP et al., 2001). VALERGA et al. (2012) investigated the relationship between polyphenol composition and the antioxidant activity of a mixture of purified commercial standards (caffeic acid, chlorogenic acid, kaempferol, quercetin, and rutin). They found that quercetin was the highest contributor followed by kaempferol and caffeic acid, while rutin and chlorogenic acid inputs were the lowest. In contrast, ANESINI et al. (2012) who investigated the participation of the main bioactive compounds on the antioxidant activity of the crude extracts of I. paraguariensis found that chlorogenic acid, caffeic acid, and rutin positively contributed to the antioxidant activity (DPPH free radical scavenging activity and the prevention of lipid oxidation) of extracts. Thus, in this study, rutin and caffeic acid, which were the phenolic compounds found at the highest concentration are probably the major contributors to the antioxidant activity of the mate extract.

The dourado fillets used in the present study

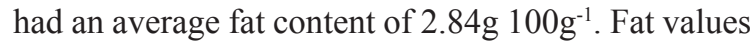
found were within the range previously reported for S. maxillosus: $0.88-4.6 \mathrm{~g} 100 \mathrm{~g}^{-1}$ (ANDRADE et al., 1995; HIANE et al., 2002). The lipid oxidative changes during the frozen storage of fillets were determined by measuring primary (CD) and secondary (TBARS) oxidation products. A significant treatment $\mathrm{x}$ storage time interaction was observed on the $C D$ values. No changes were observed in the $\mathrm{CD}$ values of fillets treated with the aqueous extract of $I$. paraguariensis (AE) during the storage. However, the CD values of control fillets increased after 6 months of storage and then decreased $(\mathrm{P}<0.05$; Figure $1 \mathrm{~A})$. In addition, at 6 months of storage the $\mathrm{CD}$ values of control fillets were higher than those of AE-treated fillets $(\mathrm{P}<0.05$; Figure 1A). The increase in the $\mathrm{CD}$ values of control fillets are probably due to the faster rate of formation of $\mathrm{CD}$ than its degradation into secondary products 

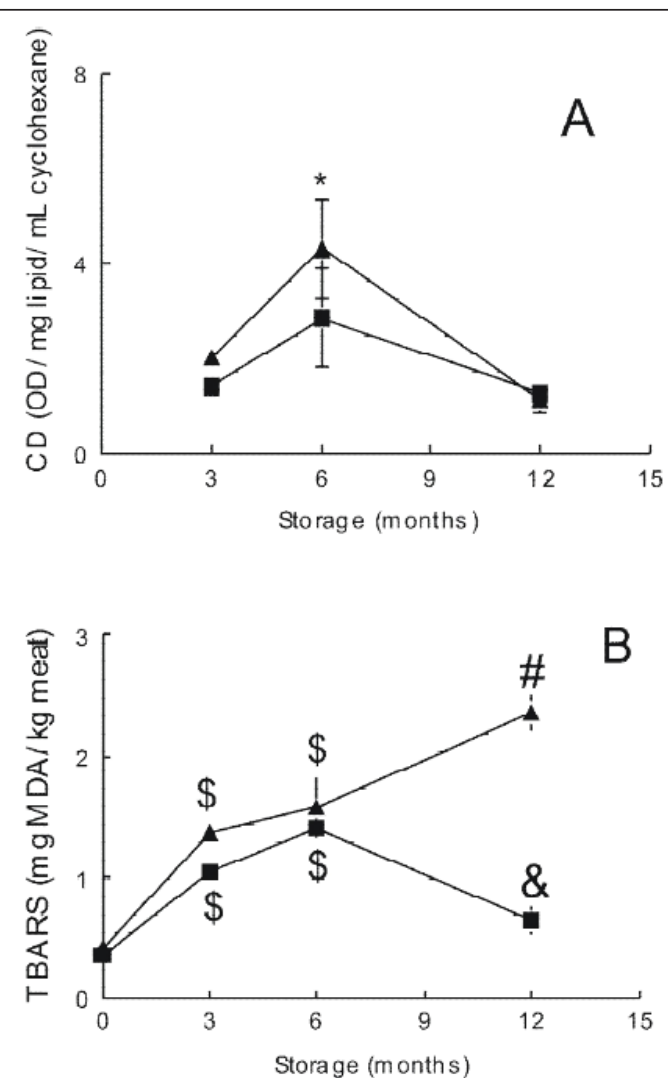

Figure 1 - Changes in conjugated dienes value (CD) (A) and TBARS value (B) of dourado fillets treated with aqueous extract of $\boldsymbol{I}$. paraguariensis during frozen storage. Control, distilled water

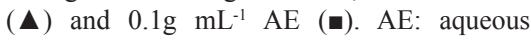
extract of $\boldsymbol{I}$. paraguariensis. Values are means \pm standard error $(n=3)$. OD $=$ optical density. *Significantly different from all other groups $(\mathrm{P}<0.05)$. ${ }^{\text {SSignificantly different from }}$ the same treatment at zero month of storage $(\mathrm{P}<0.05)$. "Significantly different from the same treatment at 0,3 and 6 months of storage $(\mathrm{P}<0.05) .{ }^{\&}$ Significantly different from control at 12 months of storage $(\mathrm{P}<0.05)$.

during the first six months of storage. On the other hand, the decrease in $\mathrm{CD}$ values after six months of storage may reflect its higher degradation into secondary oxidation products. Thus, the unchanged $\mathrm{CD}$ levels in the AE-treated fillets suggest that the extract may either prevent $\mathrm{CD}$ formation or accelerate its degradation into secondary oxidation products.

A significant treatment $\mathrm{x}$ storage time interaction was also observed on the TBARS values (Figure. 1B). The TBARS value of the control fillets increased up to the $12^{\text {th }}$ month of storage $(\mathrm{P}<0.05)$. However, TBARS of AE-treated fillets had a small increase up to 6 months of storage and then decreased $(\mathrm{P}<0.05)$. At the twelfth month of storage the TBARS value of AE-treated fillets was significantly lower than control fillets $(\mathrm{P}<0.05)$. Aldehydes resulting from lipid peroxidation such as MDA and 4-OH-nonenal are responsible for the characteristic rancidity odor and rejection of oxidized foods (HAMRE et al., 2003). According to GILL (1990) a TBARS value in the range of $1-2 \mathrm{mg} \mathrm{MDA} \mathrm{kg}{ }^{-1}$ of fish sample is usually taken as the limit of acceptability. In our study, control samples exceeded this limit between the sixth and the twelfth month of frozen storage, whereas AE-treated fillets did not exceed this limit even after 12 months of storage. These results indicate that $\boldsymbol{I}$. paraguariensis can inhibit lipid oxidation in frozen fish fillets.

The color parameters of dourado fillets are presented in table 1. Two-way ANOVA revealed a significant treatment $\mathrm{x}$ storage time interaction on the luminosity ( $\mathrm{L}^{*}$ values) of samples. $\mathrm{L}^{*}$ values significantly increased in control fillets during frozen storage (from 6 months onwards, $\mathrm{P}<0.05$ ). However, $\mathrm{L}^{*}$ values of fillets treated with $\mathrm{AE}$ did not change during storage. Consequently, L* values of control and AE-treated fillets were not different at the start of frozen storage, but after 12 months of storage the fillets treated with $\mathrm{AE}$ had lower $\mathrm{L}^{*}$ values than control $(\mathrm{P}<0.05)$. According to MORKORE (2006), the increased $\mathrm{L}^{*}$ value can be related to protein conformational changes that could change the reflection of the incident light. It is possible that protein oxidation had accompanied the significant increase of TBARS value in control fillets after 12 months of storage, and it could be responsible for $\mathrm{L}^{*}$ changes. This proposal is consistent with the stability of $\mathrm{L}^{*}$ values in fillets treated with AE (Table 1), since these samples had remarkably lower lipid oxidation (CD and TBARS values) as compared to control fillets (Figure 1). These results suggest that mate extract could delay protein oxidation in dourado fillets during frozen storage, although such oxidation was not directly measured.

There was a significant effect of storage time on $a^{*}$ values, but no significant effect of treatment (Table 1). The decrease in redness $\left(a^{*}\right.$ values) observed both in control and AE-treated fillets after 6 months of storage $(\mathrm{P}<0.05)$ was possibly due to the autoxidation of myoglobin (WETTERSKOG \& UNDELAND, 2004).

There was a significant effect of storage time and AE treatment on the yellowness ( $b^{*}$ value) and saturation of color (chroma value) of fillets (Table 1). Saturation indicates how much one given color differs from the gray. In the first months of frozen storage yellowness and saturation $\left(\mathrm{C}^{*}\right.$ value) were significantly higher in the $\mathrm{AE}$ treated fillets when 
Table 1 - Color parameters of dourado fillets treated with aqueous extract of I. paraguariensis (AE) during frozen storage.

\begin{tabular}{|c|c|c|c|c|c|c|}
\hline Storage (months) & Treatments ${ }^{1}$ & $\mathrm{~L}^{*}$ & $a^{*}$ & $b^{*}$ & $\mathrm{C}^{* 2}$ & $\mathrm{H}^{* 2}$ \\
\hline \multirow{2}{*}{0} & Control & $56.97^{\mathrm{b}, \mathrm{c}}(0.69)$ & $6.53^{\mathrm{a}}(0.04)$ & $7.51^{\mathrm{d}}(0.35)$ & $9.70^{\mathrm{c}}(0.11)$ & $47.48^{\mathrm{d}}(0.60)$ \\
\hline & $\mathrm{AE}$ & $56.42^{\mathrm{b}, \mathrm{c}}(0.82)$ & $5.53^{\mathrm{a}}(0.17)$ & $10.89^{\mathrm{b}, \mathrm{c}}(0.34)$ & $12.22^{\mathrm{a}, \mathrm{b}}(0.23)$ & $61.61^{\mathrm{c}}(0.22)$ \\
\hline \multirow{2}{*}{3} & Control & $57.44^{\mathrm{b}, \mathrm{c}}(0.58)$ & $4.70^{\mathrm{a}, \mathrm{b}}(0.22)$ & $9.47^{\mathrm{c}, \mathrm{d}}(0.33)$ & $10.33^{\mathrm{c}}(0.36)$ & $63.31^{\mathrm{c}}(0.28)$ \\
\hline & $\mathrm{AE}$ & $52.54^{\mathrm{c}}(1.52)$ & $3.54^{\mathrm{a}, \mathrm{b}}(0.29)$ & $12.61^{\mathrm{a}, \mathrm{b}}(0.37)$ & $13.10^{\mathrm{a}, \mathrm{b}}(0.43)$ & $74.33^{\mathrm{b}}(0.79)$ \\
\hline \multirow{2}{*}{6} & Control & $61.22^{\mathrm{a}, \mathrm{b}}(1.65)$ & $3.65^{\mathrm{a}, \mathrm{b}}(1.71)$ & $12.49^{\mathrm{a}, \mathrm{b}}(0.99)$ & $11.74^{\mathrm{b}, \mathrm{c}}(0.99)$ & $83.50^{\mathrm{a}}(2.22)$ \\
\hline & $\mathrm{AE}$ & $60.61^{\mathrm{a}, \mathrm{b}}(0.93)$ & $1.51^{\mathrm{b}}(0.45)$ & $14.02^{\mathrm{a}}(0.22)$ & $14.10^{\mathrm{a}}(0.17)$ & $83.80^{\mathrm{a}}(1.93)$ \\
\hline \multirow{2}{*}{12} & Control & $64.13^{\mathrm{a}}(2.31)$ & $1.38^{\mathrm{b}}(0.21)$ & $13.62^{\mathrm{a}}(0.44)$ & $13.28^{\mathrm{a}, \mathrm{b}}(0.21)$ & $85.99^{\mathrm{a}}(0.95)$ \\
\hline & $\mathrm{AE}$ & $55.67^{\mathrm{b}, \mathrm{c}}(0.83)$ & $2.47^{\mathrm{b}}(0.45)$ & $14.03^{\mathrm{a}}(0.07)$ & $14.15^{\mathrm{a}}(0.05)$ & $80.39^{\mathrm{a}, \mathrm{b}}(1.37)$ \\
\hline
\end{tabular}

${ }^{1}$ Control: distilled water

${ }^{2} \mathrm{C}^{*}$ : Chroma. $\mathrm{H}^{*}$ : Hue angle

a,b,c Values are means (standard error) of three independent repetitions. Means within the same column that have no common superscript letters are significantly different from each other $(\mathrm{P}<0.05)$

compared to control $(\mathrm{P}<0.05)$, which can be explained by the presence of carotenoid pigments in the mate extract (ALIKARIDIS, 1987). Yellowness and saturation $\left(C^{*}\right.$ value) increased significantly during frozen storage in both treatments $(\mathrm{P}<0.05)$. Yellow color is often associated with lipid oxidation and has been reported to increase substantially during freezing in other fish species (HAMRE et al., 2003). Hence, the development of lipid oxidation, as indicated by the increase of TBARS value during the frozen storage of our samples is probably responsible for the associated increase of yellowness and saturation.

The hue value indicated that fillets of dourado tended to yellowness during all the experiment (Table 1), with values similar to those reported by HAMRE et al. (2003) for herring. There was a significant treatment $\mathrm{x}$ storage time interaction on the hue values. The hue values of samples treated with $\mathrm{AE}$ were higher (more tendency to yellow) than control fillets until 3 months of storage $(\mathrm{P}<0.05)$, probably due to the presence of carotenoid pigments in the mate extract. During storage $\mathrm{H}^{*}$ values of both control and AE treated fillets increased, revealing a higher tendency to yellow. This probably occurred due to lipid oxidation as discussed for changes in $b^{*}$ value. Accordingly, the $\mathrm{H}^{*}$ value of control fillets increased 1.81-fold along 12 months of storage, whereas the $\mathrm{H}^{*}$ value of AE-treated fillets increased only 1.31-fold. This is in agreement with the greater increase in lipid oxidation (CD and TBARS values) of control fillets as compared to the AE-treated fillets $(\mathrm{P}<0.05)$.

Results obtained demonstrate the possible usefulness of mate extract to extend the shelf- life of fish fillets. These results are in agreement with previous evidence that mate extract protected against lipid oxidation in processed meat products like salami stored at room temperature (CAMPOS et al., 2007) and chicken meat balls (RACANICCI et al., 2008). In addition, VALERGA et al. (2012) recently demonstrated that mate extracts inhibited MDA formation in sunflower oil $\left(20 \mathrm{mmol} \mathrm{kg}^{-1}\right)$ and $\mathrm{CD}$ production in oil/water emulsions $\left(60 \mathrm{mmol} \mathrm{kg}^{-1}\right)$. However, no other studies on the antioxidant effect of mate in foods were found.

\section{CONCLUSION}

Mate extract prevents lipid oxidation of frozen dourado fillets, as demonstrated by the lower CD and TBARS values of treated fillets when compared to the control ones. Fillets treated with mate also have less color changes (lower changes in $\mathrm{L}^{*}$ and $\mathrm{H}^{*}$ values) during frozen storage, which is probably associated to the antioxidant activity of the extract.

\section{ACKNOWLEDGEMENTS}

T.E. and M.L.A. are recipients of Conselho Nacional de Desenvolvimento Científico e Tecnológico ( $\mathrm{CNPq})$ research Fellowships. A.P.L.V. is the recipient of CNPq scholarship. Work supported by CNPq - Brasil, Edital Capes no. 27/2010 - PróEquipamentos Institucional, and Casadinho/PROCAD (MCT/ CNPq/MEC/Capes).

\section{REFERENCES}

ALIKARIDIS, F. Natural constituents of Ilex species. Journal of Ethnopharmacology, v.20, p.121-144, 1987. 
ANDRADE, A.D. et al. Omega-3 fatty acids in freshwater fish from south Brazil. Journal of the American Oil Chemistry Society, v.72, p.1207-1210, 1995.

ANESINI, C. et al. Peroxidase-like activity of Ilex paraguariensis. Food Chemistry, v.97, p.459-464, 2006.

ANESINI, C. et al. Study of the participation of caffeine and polyphenols on the overall antioxidant activity of mate (Ilex paraguariensis). LWT - Food Science and Technology, v.45, p.299-304, 2012. Available from: <http://www.sciencedirect.com/ science/article/pii/S0023643811001988>. Acessed: Jul. 6, 2012. doi: 10.1016/j.lwt.2011.06.015.

BLIGH, E.G.; DYER, W.J. A rapid method of total lipid extraction and purification. Canadian Journal of Physiology and Pharmacology, v.37, p.911-917, 1959.

BRAND-WILLIAMS, W. et al. Use of a free radical method to evaluated antioxidant activity. LWT - Food Science and Technology, v.28, p.25-30, 1995.

BUEGE, J.A.; AUST, S.D. Microsomal lipid peroxidation. Methods in Enzymology, v.52, p.302-309, 1978.

CAMPOS, R.M.L. de et al. Fatty acid and volatile compounds from salami manufactured with yerba mate (Ilex paraguariensis) extract and pork back fat and meat from pigs fed on diets with partial replacement of maize with rice bran. Food Chemistry, v.103, p.1159-1167, 2007.

FILIP, R. et al. Antioxidant activity of Ilex paraguariensis and related species. Nutrition Research, v.20, p.1437-1446, 2000.

FILIP, R. et al. Phenolic compounds in seven South American Ilex species. Fitoterapia, v.72, p.774-778, 2001.

FUKUMOZO L.R.; MAZZA, G. Assesing antioxidant and prooxidant activities of phenolic compounds. Journal of Agricultural and Food Chemistry, v.48, p.3597-3604, 2000.

GILL, T.A. Objective analysis of seafood quality. Food Reviews International, v.6, p.681-714, 1990.

GUGLIUCCI, A. Antioxidant effects of Ilex paraguariensis: induction of decreased oxidability of human LDL in vivo. Biochemical and Biophysical Research Communication, v.224, p.338-344, 1996.

HAMRE, K. et al. Development of lipid oxidation and flesh colour in frozen stored fillets of Norwegian spring-spawning herring (Clupea harengus L.). Effects of treatment with ascorbic acid. Food Chemistry, v.82, p.447-453, 2003.

HIANE, P.A. et al. Teores de colesterol e lipídios totais de seis espécies de peixes capturados na região pantaneira do estado de Mato Grosso do Sul. Boletim do Centro de Pesquisa de Processamento de Alimentos, v.20, p.65-74, 2002.

HOSSEINI, S.V. et al. Influence of the in vivo addition of alphatocopheryl acetate with three lipid sources on the lipid oxidation and fatty acid composition of Beluga sturgeon, Huso huso, during frozen storage. Food Chemistry, v.118, p.341-348, 2010. Available from: <http://www.sciencedirect.com/science/article/ pii/S0308814609006104> Acessed: Jul. 6, 2012. doi: 10.1016/j. foodchem.2009.04.131

HUNT, R.W.G. The specification of colour appearance: Concepts and terms. Colour Research Applied, v.2, p.55-68, 1977.

KOCH, W.R. et al. Guia ilustrado de peixes, Parque Delta do Jacuí. Porto Alegre: Fundação Zoobotânica do Rio Grande do Sul, 2000. 28p.

KRISHNAIAH, D. et al. A review of the antioxidant potential of medicinal plant species. Food and Bioproducts Processing, v.89, p.217-233, 2011. Available from: <http://www.sciencedirect.com/ science/article/pii/S0960308510000520>. Acessed: Jul. 6, 2012. doi: 10.1016/j.fbp.2010.04.008.

MORKORE, T. Relevance of dietary oil source for contraction and quality of pre-rigor filleted Atlantic cod, Gadus morhua. Aquaculture, v.256, p.56-65, 2006.

RACANICCI, A.M.C. et al. Mate (Ilex paraguariensis) as a source of water extractable antioxidant for use in chicken meat. European Food Research and Technology, v.227, p.255-260, 2008 .

RECKNAGEL, R.O.; GLENDE JR, E.A. Spectrophotometric detection of lipid conjugated dienes. Methods in Enzymology, v.105, p.331-337, 1984.

SCHINELLA, G.R. et al. Antioxidant effects of an aqueous extract of Ilex paraguariensis. Biochemical and Biophysical Research Communications, v.269, p.357-360, 2000.

SOYER, A. et al. Effects of freezing temperature and duration of frozen storage on lipid and protein oxidation in chicken meat. Food Chemistry, v.120, p.1025-1030, 2010. Available from: <http:// www.sciencedirect.com/science/article/pii/S0308814609013521>. Acessed: Jul. 6, 2012. doi: 10.1016/j.foodchem.2009.11.042.

STREIT, N.M. et al. Relation among taste-related compounds (phenolics and caffeine) and sensory profile of erva-mate (Ilex paraguariensis). Food Chemistry, v.102, p.560-564, 2007.

VALERGA, J. et al. Polyphenol input to the antioxidant activity of yerba mate (Ilex paraguariensis) extracts. LWT - Food Science and Technology, v.45, p.28-35, 2012. Available from: <http:// www.sciencedirect.com/science/article/pii/S0023643811002234>. Acessed: Jul. 6, 2012. doi: 10.1016/j.lwt.2011.07.022.

VERMA, J.K. et al. Effects of frozen storage on lipid freshness parameters and some functional properties of oil sardine (Sardinella longiceps) mince. Food Research International, v.28, p.87-90, 1995 .

WETTERSKOG, D.; UNDELAND, L. Loss of redness (a*) as a tool to follow hemoglobin mediated lipid oxidation in washed cod mince. Journal of Agricultural and Food Chemistry, v.52, p.7214-7221, 2004 